\title{
Sustainable Logistics Networks in Sparsely Populated Areas
}

\author{
Wei Deng Solvang*, Moulay Hicham Hakam
}

Department of Industrial Engineering, Narvik University College, Narvik, Norway.

Email:*wds@hin.no, hakam@hin.no

Received August $17^{\text {th }}, 2009$; revised November $17^{\text {th }}$, 2009; accepted December $24^{\text {th }}, 2009$.

\begin{abstract}
A logistics network is the 'connective tissue' in a comprehensive supply chain and often the decisive factor for the chain's ultimate success. Logistics networks in sparsely populated areas are facing different challenges than those that operating in relatively densely inhabited ones. This paper discusses, firstly, various critical success factors of a logistics network in order for it to sustain in sparsely populated areas. The challenges of establishing and operating a logistics network in sparsely populated areas are then identified and discussed. A case study has been conducted in the context of a region in Northern Norway where the average population rate is 4.3 persons each square kilometer. The paper suggests that, by combining reverse logistics networks with forward ones, social, economic and environmental sustainable logistics networks can be achieved. The challenges of integrating forward and reverse logistics networks in Northern Norway are discussed in the final part.
\end{abstract}

Keywords: Logistics Network, Sparsely Populated Areas, Sustainability

\section{Introduction}

A logistics network is traditionally defined as a set of resources which interactively connected with each other purposing of timely and cost-effective transfer of material and products to specified places. The definition itself doesn't limit the objects being transferred along the network, may it be material, products, services or even the end-of-life products which are also termed as waste.

Currently, challenges to logistics networks can often be seen in the context of globalization, individualization/mass customization and needs for economic development. The increasing globalization which is motivated by taking geographical advantages i.e., low-cost labor, easier access to necessary technology and local markets [1] often places huge challenges to logistics network due to, for instance, large distance among geographically scattered resources. Moreover, the increasing individualization [2] leads to the needs to mass-customized products. This requires that logistics networks which associated to these products are also able to provide mass-customized services. Further, the increasing public concerns on climate changes, environmental degradation and energy crisis as well as continuously strengthened international environmental and energy regulations lead to that a logistics network can no longer survive by taking only economic and operational performances into consideration [3-5]. That leads to the fact that economic sustainability needs to be offset by environmental sustainability in both shorter and longer terms.

Harris and Startup [6] state that all organizations attempting to provide universal geographical coverage face difficulties in supplying the populations of sparsely populated areas. The enlargement of the European Union has also accentuated differences between peripheral /sparsely populated areas and centrally/heavily urbanized areas in Europe. EEA EFTA states "that EU internal market legislation and other policy instruments should to a larger extent reflect such regional differences such that actions and legislation at EU level do not contribute to reduced competitiveness of industries in peripheral and remote areas" [7].

Currently, literatures that related to population sparseness and sustainability of its logistics networks are limited. Sandow [8] emphasizes the critical importance of labor mobility for regional competitiveness and sustainability in sparsely populated areas and further pointed that "a well functioning transport (logistics) system" is vital for securing this mobility of competent labor. Nilsson et al. [9] present another Swedish study which focuses on challenges of current low heat density areas to competitiveness of district heating in sparsely populated areas. They stated that, in order to improve the economic 
sustainability of district heating in less densely populated areas, the rate of expansion in the detached-house segment needed to be increased. Muilu and Rusanen [10] document an increasing urbanization in Finland from 1970 to 2000. Same trend can be confirmed in Norway and Sweden. According to Muilu and Rusanen [10], as Finnish population continuous to increase, the number and proportion of young people have declined in rural municipalities. This resettlement of young people from peripheral areas to the built-up ones resulted in a dichotomy between the sparsely and densely populated areas which further accentuated by the distortion of population structure and gender ratio.

According to Neto et al. [11], the increasing focus on climate changes and pollution reduction from both publics and governments in recent years has aroused great interests of as well as large pressure on how logistics networks should operate. They proclaim that the objective in design a logistic network has changed, from cost minimization only to cost and environmental impact minimization. Tsoulfas and Pappis [12] propose some environmental principles for companies to be able to obtain a sustainable supply chain. Their argument is that by obtaining sustainable functions inside, outside and among companies along the chain, a competitive supply chain can be achieved in a long-term perspective. The logistics function is defined as one of five focuses in their research. Unfortunately, the study is still on conceptual level and hasn't provided any practical measures that can be used for logistics networks to achieve their sustainability.

This paper aims to shed light on challenges to economic and environmental sustainability of logistics networks in sparsely populated areas. The economic and environmental sustainability are interrelated and need to be detailed into some manageable concepts. Therefore three critical success factors are explored and discussed in the section that followed. A review of forward and reverse logistics networks is conducted purposing to provide the theoretical background for a case study of current logistics networks in Northern Norway. Based on the analysis on current logistics networks, the authors give several suggestions on how economic as well as environmental sustainability might be improved in these networks.

\section{Critical Success Factors for the Success of Logistics Networks that Operating in Sparsely Populated Areas}

A logistics network is a critical element for national, regional and community development, especially in a fragmented landscape with high demographic sparseness. Providing necessary level of logistics excellence in such an area prevents depopulation from the region and is vital for the region's economic development. Comparing with logistics networks in densely populated areas, those in sparsely populated areas are facing different strategic and operational challenges.

Generally, an organization may sustain when competing with any of three advantages, namely, overall cost leadership, differentiation and focus [13]. The first factor is concerned with cost-effectiveness; the second represents the uniqueness of the product as perceived by the customer. As for the third factor, the key idea is to serve a particular target very well.

One of the most significant differences between densely and sparsely populated areas is the size of population a logistics network aims to serve. A densely populated area has usually large enough concourse which provides necessary basis for the network to take the advantages of both economy-of-scale and economyof-scope. Logistics networks in sparsely populated area, however, usually do not possess necessary prerequisites for taking these advantages.

Another difference is the distance. A logistics network in a densely populated area is less distant between two resources (i.e., between a distribution centre and a retailer). This may easily enable, for example, the network to achieve more mass-customized logistics service with diverse focuses.

The third difference is that a sparsely populated area is usually situated in a peripheral region of a country. Developing logistics networks that connecting sparsely and densely populated areas needs to be viewed in conjunction with offering universal geographical coverage for social and economic development as well as sustainable regional development in whole territory. By doing so, risks such as social degradation and depopulation can be prevented or minimized.

Different strategies needs to be applied to handle the challenges mentioned above. The critical success factors for logistics networks operating in sparsely populated areas are therefore:

- Cost-effectiveness: refers to the extent to which customer requirements are met given a limited level of cost.

- Cost-efficiency: a measure of how economically a network's resources are utilized when providing a given level of customer satisfaction.

- Eco-efficiency: the efficiency with which resources are converted into product.

\section{Forward and Reverse Logistics Network}

As mentioned earlier, a logistics network links difference resources in the way that tangible or intangible objects (i.e., material, parts, products, service and waste) being transferred within the network and towards a clearly defined destination. While a forward logistics network brings raw material or new products from origin (e.g., a 
raw material supplier) to end-customers, a reverse network refers to the network structure dealing with the end-of-life products from end-customers (Figure1, made based on [14]).

Reverse logistics is the process of moving goods from their typical final destination to another point, for the purpose of capturing value otherwise unavailable, or for the proper disposal of the products [14].

In recent years, the term 'closed-loop supply chain' has becoming a topical issue as increasing attention has been attached to pollution prevention and minimization rather than end-of-pipe pollution control [4]. A Closedloop supply chain can be regarded as a system without waste. The primary material flow of forward logistics network has been linked with material flow of reverse logistics network through waste dis charge and management system (direct treatment, indirect treatment and purification). The closed-loop supply chain system can also achieve high level of logistics excellence as capacity of forward and reverse logistics network can be utilized optimally.

\section{Case study}

Norway has especially fragmented territory and Norwegian territorial structure can be characterized as [15]:

- $\quad$ Long distance to main markets

- Extensive mountain areas

- Insular and coastal regions

- Isolated border regions

- Arctic and sub-arctic climate

- Demographic sparseness

- An extremely diffused urban system with sharp differences regarding settlement structures, functional profiles and centralities

Norway is ranked 214 out of 241 countries according to average population density based on data for 2005 [16].

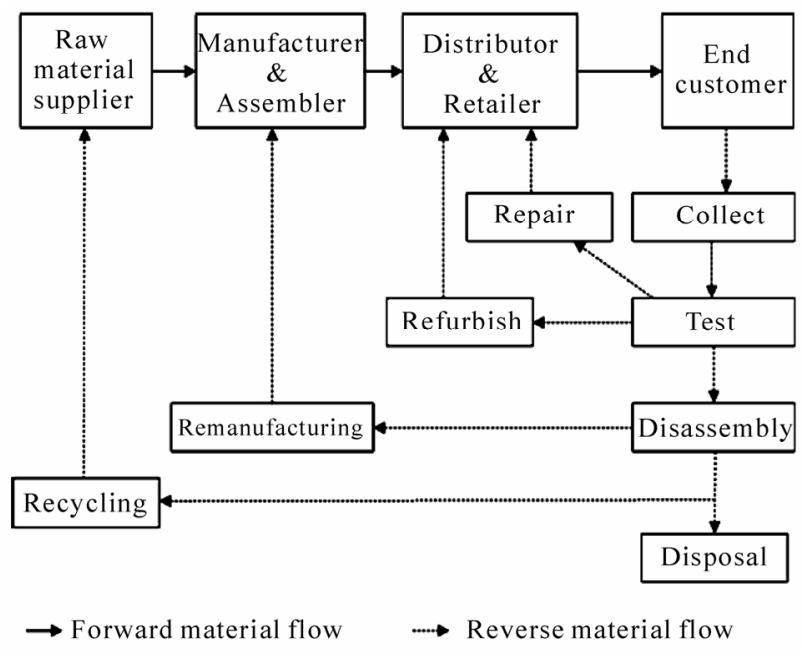

Figure 1. Forward and reverse logistics networks
The population density is 15.4 persons per each square kilometer (Table 1). Areas with less than 12.5 persons per square kilometer cover $87 \%$ of the land area. 286 of 430 municipalities has population density lower than 12.5 persons per square kilometer.

Norway has nineteen counties. Among which, three of them are in Northern part of Norway (Nordland, Troms and Finnmark, as shown in Table 1). The area of this part counts up to $106,715 \mathrm{~km}^{2}$ and is over $35 \%$ of total Norwegian territory. In 2007 , less than $10 \%$ of Norwegian population is resident in this part and population density is 4.3 persons per square kilometer. This extremely low population density places huge challenge to the development and sustainability of the logistics networks within this region. The long distance between the Northern and Southern parts of Norway also places fierce challenge to sustainability of their connecting logistics networks.

\subsection{Current Logistics Networks that Link North with South}

\subsubsection{Staple Goods and Fishes}

Currently, the main stream of staple goods (i.e., food, mail) from south to north is carried by Arctic Rail Express (ARE) which is an established service offered by CargoNet [17]. Yearly, up to 23,500 containers (either twenty feet or twenty-five feet container) are carried by ARE train from Oslo Alnabru to Narvik through Swedish territory (Figure 2). The whole journey takes 27 hours

Table 1. Population density in Norway (2007 data) ${ }^{\mathrm{A}}$

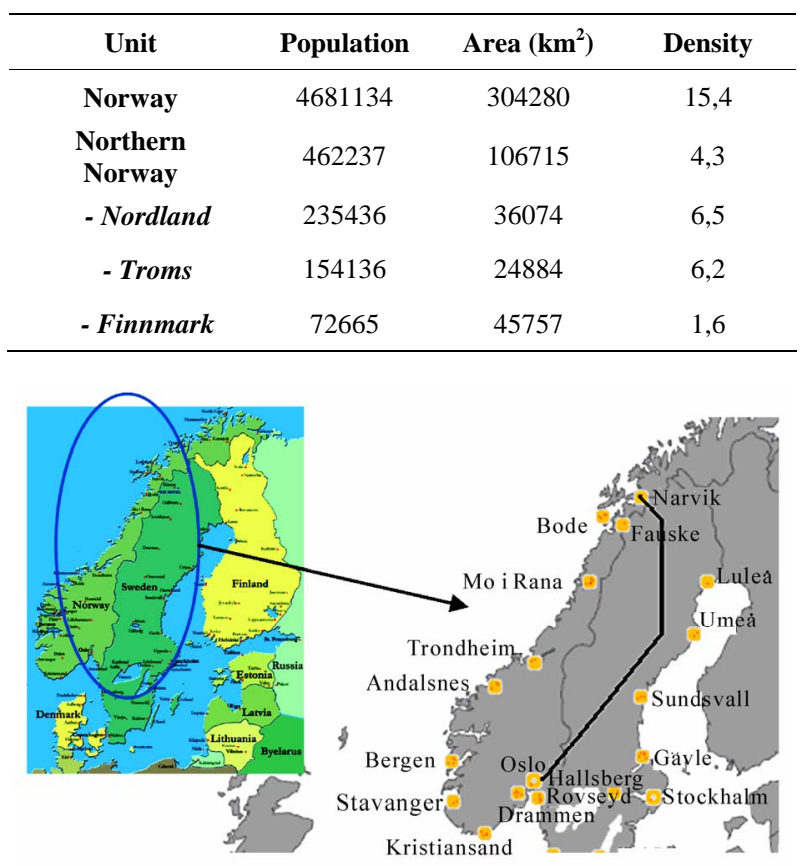

Figure 2. ARE train 
and total length of railway is $250 \mathrm{~km}$. These goods are further distributed to three main regions (Tromsø, Harstad and Narvik) by third party logistics providers (3PL) (i.e., Schenker and Nor Cargo). These further transportations are conducted on road. 55\% (approx. 13,000 containers) of the staple goods travel around $250 \mathrm{~km}$ to Tromsø, 10\% being transported $135 \mathrm{~km}$ to Harstad, and 35\% being distributed in local Narvik area (Figure 3).

According to CargoNet, the back loading rate of ARE is barely $60 \%$. Of which the majority is raw fish and fish products. This means that nearly 9,500 containers return empty from Narvik back to Oslo. There is no doubt a considerable potential in cost-efficiency improvement.

The ARE runs twenty-two trains each week. That is eleven trains in each direction. Together with other 3PLs, ARE satisfies basic demands (food, communication) of Northern Norway with a population of nearly 470,000. Eco-efficiency is satisfactory considering the transportation is mainly on railroad.

\subsubsection{Wastes}

It is said that the waste amount is increasing as the economy is accelerating in a region. Since 1995, the entire amount of wastes in Norway has been increased by nearly $30 \%$ and has already reached 9,6 million tons in 2006 [18]. Recognizing this, the Norwegian government has, since 1970s, been working systematically in establishing a sustainable waste management system.

In Norway, the enactment of Product Control Act in 1976 and Pollution Control Act in 1981 as well as Product Responsibility Act in 1988 established the fundament for crystallizing the 'polluter pays' principle to entire nation. Various environmental legislations are enacted since 1980s with purpose of promoting pollution prevention and pollution minimization (through reuse and recycling) and avoiding waste being deposed in landfills.

Currently, sixteen waste management companies are established in Northern Norway handling up to 900,000 ton wastes per year (the volume is calculated based on data from Statistics Norway). Take one of the waste management companies in Northern Norway as an example, Hålogaland Ressursselskap (HRS) is an intra-municipal companies which owned by twelve municipalities. Its activities consist of collecting, sorting, transportation and treatment of household, industrial and special wastes (Figure 4).

Its current waste is categorized as:

- glass and bottles

- timber

- iron

- food waste

- $\quad$ paper

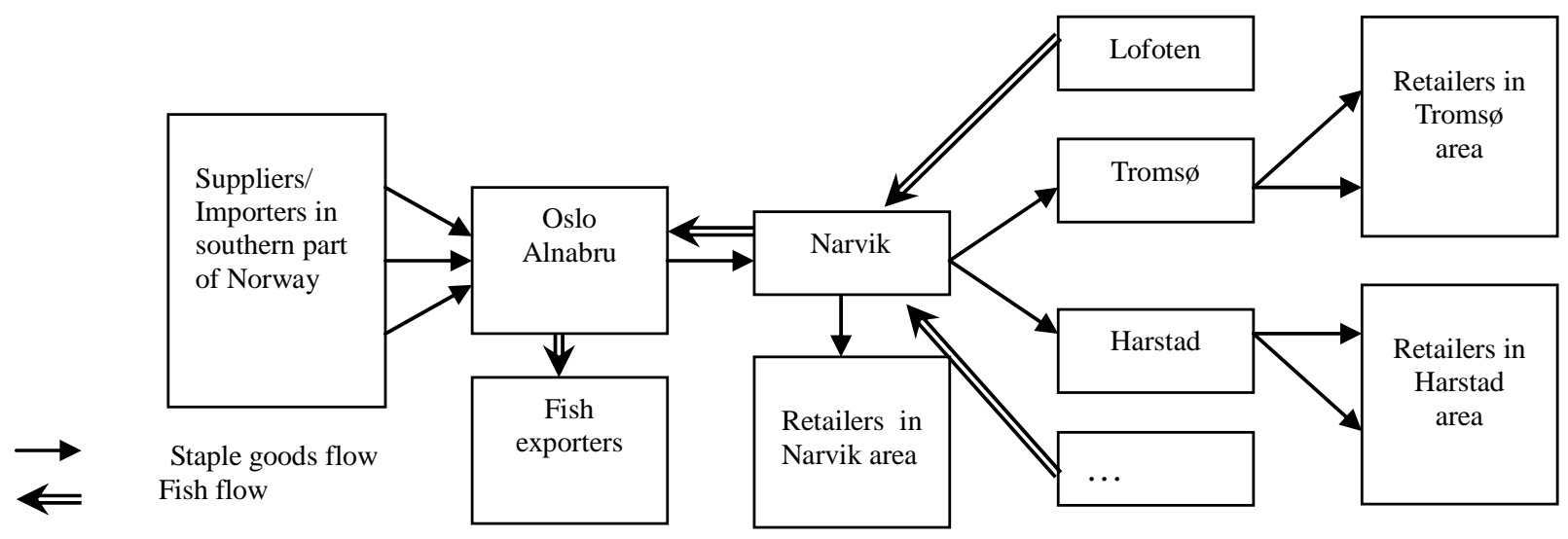

Figure 3. Main material stream south-to-north and north-to-south with Narvik as intersection

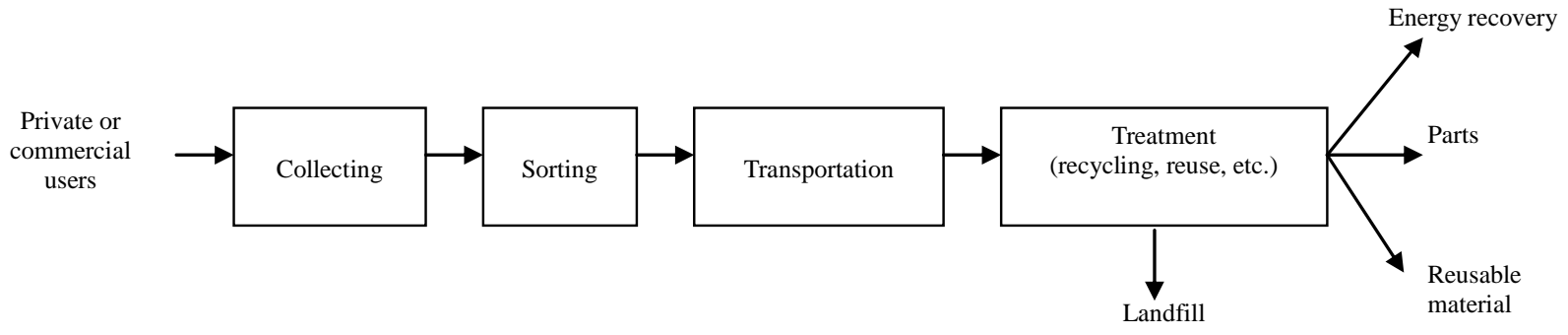

Figure 4. Reverse logistic processes 
- corrugated cardboard

- plastics from industries

- beverage paperboard box

- waste of electrical and electronic equipment (WEEE)

- hazardous waste

Most of the waste goes to recycling, nearly $90 \%$ in 2005. Taking this as key figure, the recycling volume can be estimated up to around 800,000 tons in Northern Norway.

Currently, large portion of the recyclable wastes is transported to the Southern part of Norway where the majority of recycling facilities are. The transportation is mainly on road with trucks or semi-trailers.

\subsection{The Potential and Challenges of Integrating Forward and Reverse Logistics Networks}

It is undoubtedly that there is a huge potential of integrating forward logistic network (of staple goods and fish) with reverse logistics network (of wastes) with Narvik as the junction point. By doing so, the biggest gain is the reduction of empty container back to Oslo. This will, to a large extent, increasing cost-efficiency of both logistics networks. This will also lead to the reduction of transportation price. Together with regular as well as frequent transportation between south and north, a cost-effective logistics network can be achieved. Further, as the integration will 'lift' goods from road to track, significant environmental profit (i.e., less pollution and noise) and social gains (i.e., less traffic accidents) can be obtained.

However, challenges for this integration are many. First of all, current waste management system has obtained itself an exclusive logistics network. Take Elretur AS for example, as one of four take-back companies approved by Norwegian Pollution Control Authority (SFT), Elretur AS collects over 76,000 ton WEEE in 2007. The company cooperates with seven 3PLs for collecting from entire Norway [19]. One of these companies is Østbø AS which has full authority and responsibility for collection of WEEE in Northern Norway. Østbø AS has its own closed system for transporting WEEE to treatment plants in Southern part of Norway. The transportation from Northern Norway to Østbø AS and from Østbø AS to Southern Norway is mainly on road.

Secondly, the hygienic requirements of transporting foods and other staple goods from south to north may place the challenge to return wagons loaded by wastes. The traditional perception of waste may also create scepticism at staple goods owners and therefore may result in reduced logistics flow from south to north.

\section{Summary and Discussion}

The paper presents a conceptual study on logistic networks in sparsely populated area. As opposite to densely populated areas, sparsely populated ones place larger challenge to their logistic networks. The limitations of such areas include that the demand volume does not justify economy-of-scale or economy-of-scope. Larger distance between two resources within a network is also a significant challenge. That a sparsely populated area usually situated in a peripheral to densely populated ones place also the challenge to the logistics connection of these areas.

This paper proposed three critical success factors for logistics networks operating in sparsely populated area. By conducting the case study, the authors argued that, in order to achieve cost-efficiency, cost-effectiveness and eco-efficiency of main logistics network that connecting Northern Norway with the Southern part, the potential of utilizing existing south-north logistics network (for staple goods and fish) for north-south transportation of wastes is considerably large. However, currently exclusive waste management systems and traditional perception of waste may place the largest challenges to this possible solution.

Benchmarking of performances in terms of cost- effectiveness, cost-efficiency, and eco-efficiency of current logistics networks (separated networks for staple goods and waste) with that of suggested logistics network (transport waste with logistics network of staple goods) need to be conducted in order to provide the quantified justification for the suggested solution. The authors also suggest that a study that mapping all goods flows at a more detail level should be conducted in order to provide an overall optimal logistics solution in Northern Norway.

\section{Acknowledgment}

The authors have received great support from different organizations and companies during this study. Here we would thank especially Jan Viggo Fredheim at CargoNet, Line Dalhaug at HRS and Ole Viggo Svendsen at Elretur AS for enthusiasm and information.

\section{REFERENCES}

[1] S. Chopra and P. Meindl, "Supply chain management strategy, planning, and operation,” Pearson Educational International, 2004.

[2] E. Alfnes, "Enterprise reengineering - a strategic framework and methodology," Department of Production and Quality Engineering, Faculty of Engineering Science and Technology, Trondheim, Norwegian University of Science and Technology, 2005.

[3] F. Du and W. Evans, "A bi-objective reverse logistics network analysis for post-sale service,” Computers and Operations Research, pp. 2617-2634, 2008.

[4] W. D. Solvang, “Architecture for supply chain analysis and methodology for quantitative measurement of supply chain flexibility,” Department of Production and Quality 
Engineering. Trondheim, Norwegian University of Science and Technology, 2001.

[5] W. D. Solvang, Z. Deng, and B. Solvang, “A closed-loop supply chain model for managing overall optimization of eco-efficiency," IN POM (Ed.) POMS 18th Annual Conference. Dallas Texas, USA, 2007.

[6] C. C. Harris and R. Startup, "Researching a traditional territorial organization: Analogy, and the sociological imagination," International Journal of Sociology and Social Policy, Vol. 18, 1998.

[7] European Economic Area Standing Committee of the EFTA States, EEA EFTA Comment on the EU Freight Transport Agenda, 27 February 2008.

[8] E. Sandow, "Commuting behaviour in sparsely populated areas: Evidence from northern Sweden," Journal of Transport Geography, No. 16, pp. 14-27, 2008.

[9] S. F. Nilsson, C. Reidhav, K. Lygnerud, and S. Werner, "Sparse district-heating in Sweden," Applied Energy, No. 85, pp. 555-564, 2008.

[10] T. Muilu and J. Rusanen, "Rural young people in regional development - the case of Finland in 1970-2000,” Journal of Rural Studies, No. 19, pp. 295-307, 2003.

[11] J. Q. F. Neto, J. M. Bloemhof-Ruwaard, J. A. E. E. van Nunen, and E. van Heck. "Designing and evaluating sustainable logistics networks," International Journal of Production Economics, No. 111, pp. 195-208, 2008.
[12] G. T. Tsoulfas and C. P. Pappis, "Environmental principles applicable to supply chains design and operation," Journal of Cleaner Production, No. 14, pp. 1593-1602, 2006.

[13] M. E. Porter, "Competitive strategy - techniques for analyzing industries and competitors," The Free Press, 1980.

[14] S. K. Scrivastava, "Network design for reverse logistics," The International Journal of Management Science, pp. 535-548, 2008

[15] J. Sandal and O. Godal, "Norwegian input to the EU green paper on territorial cohesion,” In Royal Ministry of Local Government and Regional Development, N. (Ed.), 2008.

[16] List_of_countries_by_population_density available at: http://en.wikipedia.org/wiki [Last checked: November 2009].

[17] Cargonet webpage available at: http:// cargonet.no /Wide Page.aspx?id=3729\&lang=NO [Last checked: November 2009].

[18] Norwegian statistical data available at Statistics Norway: www.ssb.no [Last checked: November 2009].

[19] Elretur webpage available at: http://www.elretur.no/nor/ Elretur/Retursystemet/Transportoerer, Last checked: November 2009. 